Ирина Кузнецова

\title{
БЕЖЕНЦЫ ИЗ УКРАИНЫ: МИГРАЦИОННАЯ ПОЛИТИКА И ПОВСЕДНЕВНОСТЬ
}

С весны 2014 г. в Россию, по разным оценкам, прибыло более 1 млн беженцев из Юго-Восточной Украины. Используя не формальное юридическое определение «беженца», а самоидентификацию, статья базируется на результатах интервью с людьми, вынужденно покинувшими Украину в результате военных действий, а также с представителями российских НКО, диаспор и миграционными экспертами. Теоретическими рамками исследования являются концепция тактик Мишеля де Серто, интерсекциональность и концепция «полу-легальности». Упрощенный режим получения российского гражданства и разрешения на временное проживание для выходцев из Юго-Восточной Украины не решают жизненные потребности беженцев. Программа по содействию добровольному переселению в Российскую Федерацию соотечественников не учитывает повышенную нуждаемость лиц, покинувших территорию военных действий в различных видах ресурсов, выступает проблематичной с точки зрения ограниченности выбора регионов и сложности участия в ней пожилых. Неопределенность правового статуса и барьеры для натурализации в России привели к тому, что потенциал формирования безопасных пространств жизнедеятельности беженцев имеет множество ограничений. В ситуации нехватки институтов, решающих проблемы беженцев и мигрантов, и проблем со статусом пребывания в России большую роль в повседневных тактиках, формирующих пространство беженцев, играют сети знакомств и неформального знания. Ситуация «полу-легальности» наиболее остро сказывается на их повседневности, в особенности пожилых и тех, кто обладает наименьшими материальными ресурсами. Для формирования устойчивого пространства повседневности беженцев необходима слаженная работа государственных и негосударственных институтов по преодолению социальных и правовых проблем, вызванных

Ирина Борисовна Кузнецова - к.с.н., доцент, старший научный сотрудник, Школа географии, Земли и наук об окружающей среде, Университет Бирмингема, Бирмингем, Соединенное королевство. Электронная почта: i.kuznetsova@bham.ac.uk 
вынужденной миграцией, своевременное информирование о различных вариантах натурализации либо возвращения. Характер этого пространства во многом будет зависеть от отношения принимающего сообщества к «другим», как в повседневном взаимодействии, так и в устойчивых практиках институтов.

Ключевые слова: беженцы, Украина, повседневность, миграционная политика, убежище

DOI: $10.17323 / 727-0634-2018-16-4-577-594$

Начиная с апреля 2014 г. в связи с вооруженным конфликтом Украина столкнулась с проблемой массовой вынужденной миграции граждан из юго-восточных областей. С тех пор более 2500 гражданских лиц получили ранения и девять тысяч погибли, 3,4 миллиона людей нуждаются в гуманитарной помощи в результате продовольственной нехватки, нарушенной инфраструктуры и рисков, связанных с продолжающимися боевыми действиями (ООН 2018). Согласно ООН, свыше 1,3 млн чел. стали беженцами, большая часть которых обратилась за убежищем в Россию и Беларусь (UNHCR 2016). Около 1,5 млн чел. остаются внутренне перемещенными лицами на территории Украины (IOM 2018).

«Термин беженец относится к словарю Женевских конвенций, и миграционные потоки 2014-2015 из Восточной Украины в Россию не соответствуют правовым критериям данного термина» (Гулина 2016:339), несмотря на это, политики, СМИ, и население активно использовали понятие «беженец» в отношении людей, вынужденно покинувших юговосток Украины. В эмпирической части исследования, на базе которого строится статья, для отбора респондентов мы использовали самоидентификацию людей как беженцев вне зависимости от их правового статуса. Употребляя понятие «беженец», мы имеем ввиду людей, вынужденных мигрировать в результате военных действий.

С самого начала прибытия беженцев из Украины Россия организовала пункты временного размещения в приграничных районах и содействовала перемещению вынужденных мигрантов в различные регионы страны. Часть беженцев, в особенности люди с ограниченными возможностями здоровья, многодетные семьи и одинокие матери, размещались в санаториях, пионерских лагерях, которым государство перечисляло средства для питания и проживания. По данным ВЦИОМ, в 2014 г. был всплеск благотворительности и волонтерства, многие активно подключились к помощи беженцам (ВЦИОМ 2014). Большую координационную работу проводили федеральная и региональные Общественные палаты РФ, консолидирующие усилия властных, коммерческих структур и гражданского общества.

По прошествии нескольких лет стало очевидно, что одновременно со снижением потока беженцев и угасанием внимания СМИ, закрытием 
пунктов временного размещения с 1 января 2017 г., внимание общественности снижается. Как отмечают исследователи, «на концептуальном уровне российская миграционная политика пока далека от восприятия украинских мигрантов как важного трудового и демографического ресурса для развития страны» (Рязанцев, Скоробогатова 2016: 38). Вынужденные мигранты из Украины сталкиваются с множеством барьеров при поиске работы, жилья (Stegniy et al. 2016). Бо́льшая часть исследований, касающихся беженцев, проводилась в психологическом ключе (Панич, Агапова 2015; Константинов, Мали 2016), анализа масс-медиа (Mukomel 2017; Змеева, Сулейманова 2015), количественных опросов беженцев (Волкова и др. 2016; Stegniy et al. 2016), либо в рамках отношения принимающего сообщества (Бойко 2015; Голубь, Безрукова 2015). Данная работа позволит проследить особенности размещения, трудоустройства и получения беженцами правого статуса посредством анализа интервью с ними, а также с представителями НКО, диаспор и экспертным сообществом. Показаны проблемы несоответствия миграционной политики потребностям отдельных категорий перемещенных лиц.

Теоретическими рамками исследования выступает интерсекциональность, концепция тактик Мишеля де Серто и понятие «полу-легальности». С точки зрения интерсекционального анализа (см.: Anthias 2012; Yuval-Davis 2011 и др.), необходимо учитывать множественные социальные структуры и процессы, которые переплетены с производством социальных позиций и идентичностей, в особенности гендера, возраста, этничности, класса. Другим аспектом интерсекциональности выступает необходимость учета контекста (Bürkner 2012). В этой связи представляется важным обращение к непосредственному опыту перемещенных лиц и их тактикам совладания с переездом. Следуя де Серто, различающим стратегии институтов власти и тактики людей, имеющих собственные способы совладания с социальными и экономическими проблемами (Certeau 1984; Раунд и др. 2010), в статье будут использоваться результаты анализа нормативно-правовой базы, позиции властей и НКО, а также опыта беженцев. Учитывая роль неформальных отношений в России и странах СНГ (см.: Williams et al. 2014), проанализирована их роль в повседневных тактиках. Работа также обращается к концепту «полу-легальности», охватывающему «промежуточные», неоднозначные статусы мигрантов (Kubal 2013).

Исследование включает в себя глубинные и полуструктурированные интервью с перемещенными лицами $(\mathrm{n}=60)$, с представителями НКО, диаспор и благотворительных фондов, с экспертами в области миграции $(\mathrm{n}=25)$. Полевой этап пришелся на 2016-2017 гг., что позволило проследить тактики беженцев, прогресс в получении и/или продлении документированного статуса, барьеры, влияние меняющейся правовой базы и правоприменения. Большинство интервью проводились в Казани, Москве, Московской области, Калуге, Воронеже и Владивостоке. Для интервью 
отбирались лица в возрасте старше 18 лет, указавшие, что они выехали из Юго-Восточных областей Украины в результате военных действий. Среди респондентов примерно равное количество мужчин и женщин различных возрастных групп. В выборку попали лица с различным официальным статусом - лица, которым предоставлено временное убежище, трудовые мигранты, лица без официального иммиграционного статуса и другие категории мигрантов. Не попали лица, которые выехали в результате политического противостояния и/или индивидуального преследования. Для отбора респондентов среди беженцев использовалась тактика «снежного кома», поскольку она позволяет исследовать конфиденциальные темы в скрытых сообществах. Каждый раз респондент(ка), отобранный(ая) через группы в социальных сетях или знакомых, представлял(а) рекомендации, к кому еще можно обратиться за интервью, и только один новый информант отбирался среди предложенных кандидатов (см.: Atkinson, Flint 2001). Поскольку исследование проводилось в удаленных друг от друга географических областях, снижалась вероятность наличия множественных знакомств среди респондентов. Интервью с беженцами конфиденциальны и полностью исключают возможность идентификации респондентов.

\section{Правовое положение украинских беженцев в России}

Статус людей, вынужденно покинувших зону военных действий в Украине, в России квалифицировался чаще всего как «лица, получившие временное убежище». Так, в 2014 г. такой статус получили 234 тыс. чел., в 2016-311 тыс., в 2016-226 тыс. и в 2017-123 тыс. (Госкомстат России 2018). Статус «беженца» с 2014 по 2017 гг. получили 854 чел. из Украины (Госкомстат России 2018). По заявлению начальника главного управления по вопросам миграции МВД России Кирилловой, сегодня в стране находятся порядка 2,5 млн украинских граждан, более миллиона из которых выходцы из Юго-Восточных областей Украины (Новости Интерфакс 2018).

Несмотря на подписанную в 1992 г. Конвенцию о защите прав беженцев 1951 г. и ее реализацию с 1993 г. с момента принятия Федерального Закона «О беженцах», политика России в отношении предоставления убежища остается сдержанной. Согласно отчету комитета «Гражданское содействие», Россия не соблюдает всех безусловных принципов Конвенции (Буртина и др. 2015). К примеру, РФ предоставила статус беженца только 0,2\% сирийцев, обратившихся за убежищем, тогда как Великобритания $85 \%$ (Denisova 2018). В результате многие сирийцы вынуждены быть трудовыми либо недокументированными мигрантами (Kubal 2016).

Какой статус предлагается лицам, вынужденно покинувшим Донбасс? Россия не впервые принимает такое количество беженцев. После распада СССР в 1990 гг. большая доля лиц, получивших временное убежище или статус 
беженца были гражданами советских республик (Мкртчян 2002). В отношении беженцев из постсоветского пространства распространялась скорее политика репатриации, которая давала возможность получать гражданство, но не включала большого количества элементов социальной интеграции (Pilkington, Flynn 1999). Исключением не стала и политика в отношении беженцев из Украины, многим пришлось воспользоваться Программой переселения соотечественников и другими механизмами получения гражданства. В мае 2016 г. принят закон, упрощающий получение вида на жительство для беженцев и лиц, получивших временное убежище в России (Федеральный закон 2016). Теперь данные категории граждан, а также участники госпрограммы по добровольному переселению соотечественников, проживающих за рубежом, могут получить вид на жительство без оформления разрешения на временное проживание. Вид на жительство дает право на пенсионное обеспечение, изменение места проживания, трудоустройство без разрешения на работу, ипотечные кредиты, избирательные и другие права. Согласно данным МВД, из получивших российское гражданство иностранцев в 2015 г. треть- бывшие граждане Украины (Петров 2016), однако неясно, какую долю из их числа составляют беженцы. Всего же за 2014-2017 гг. и первое полугодие 2018 г. гражданство РФ приобрели более 312 тыс. граждан Украины (Новости Интерфакс 2018).

В качестве других преференций в отношении правового статуса беженцев с Украины можно отметить, что им не нужно выезжать за пределы России, чтобы продлить миграционный учет, в то время как граждане Украины, не пострадавшие от военных действий, с ноября 2015 г. могут находиться в России не более 90 дней в течение полугода без разрешительных документов. Также Россия стала признавать документы, выданные гражданам Украины, проживающим на территориях отдельных районов Донецкой и Луганской областей Украины (Президент России 2017), что значительно облегчило возможности беженцев в трудоустройстве и образовании. Отмечая усилия российских властей по содействию вынужденным мигрантам с Украины, Верховный комиссар ООН по делам беженцев Филиппо Гранди заявил, что он очень надеется на помощь России в приеме беженцев, в том числе из Сирии (ТАСС 2017). Это демонстрирует своего рода исключительность российской миграционной политики в отношении выходцев с Украины по сравнению с беженцами из других государств.

\section{Совладание с вынужденной миграцией: роль неформальных сетей, государства и сообщества}

Согласно нашему исследованию, выбор России как страны убежища был продиктован следующими группами причин: (1) наличие родственников и друзей; (2) экстренная эвакуация из зоны боевых действий с помощью российских гуманитарных служб; (3) экономические мотивы (надежда найти работу); (4) соображения личной безопасности (боязнь 
судебного разбирательства в Украине; боязнь дискриминации); (6) наличие российского гражданства у одного из членов семьи. Так, одну из респонденток вместе с семьёй позвала в Казань ее знакомая, которая сама выехала из Донецка сразу же, как начались военные действия:

Позвонила и говорит,- «у вас там вообще, типа, ужас?». Я говорю: «да, вообще ужас!». Она говорит: «давай, я вышлю денег на дорогу и приезжайте сюда». Я говорю,- «давай». Нам уже было реально просто все равно, куда ехать. Вот все равно, потому что вот какая-то была работа, мы жили прекрасно, строили планы, ну, а тут мы просто существуем. Просто существуем и едим картошку с огорода и не знаем, что будет дальше и вообще (женщина, 25 лет).

Экономические мотивы наряду с родственными были наиболее распространенными. В ряде случаев беженцы имели опыт работы и знакомства для трудоустройства в России. В отдельных случаях люди без подобного опыта мигрировали, произведя макроэкономический расчет:

Я, конечно, предлагала в Днепропетровск ехать, потому что у него там все-таки родственники и как-то все-таки ближе к Донецку, в Донецке тоже родственники остались (...). Но все-таки подумали, что ситуация улучшаться не будет. И мы посмотрели, сколько уж долгов у Украины (женщина, 25-30 лет).

Как правило те беженцы, кто ехал к родственникам и знакомым, размещались самостоятельно. Многие из тех, кто был эвакуирован в экстренном порядке, были размещены в Ростовской области в пунктах временного пребывания, откуда потом их направляли в различные регионы России в квотном порядке. Так, очень скоро Москва и Санкт-Петербург стали недоступны для регистрации временного убежища. Беженцы, которые имели родственников или знакомых, смогли адаптироваться во многом благодаря наличию места проживания и неформальным социальным сетям. Зачастую содействие охватывало буквально все этапы переезда и устройства на новом месте. Весьма показательна ситуация одной из респонденток, приехавшей по приглашению подруги:

[Имя], она нас позвала. Говорит, приезжаете сюда, работу...все найдём. Нам было просто все равно куда ехать. Лишь бы куда-нибудь оттуда уехать. Потому что состояние аффекта, когда ты сидишь на пороховой бочке. Таким образом мы приехали в Москву, там нас еще одна женщина встретила, ну, чья-то родственница, чтобы нас просто провести и посадить на казанский поезд. Приехали мы в Казань, [Имя] нас встретила, и мы в первое время жили у ее родственников, которые тогда не жили в квартире в [район], вот и мы там жили, пока муж не заработал денег (женщина, возраст скрыт по соображениям анонимности).

Женщине и ее семье помогла не только подруга, но ее знакомые и родственники. Через два дня после переезда в Казань ее муж смог 
устроиться на работу благодаря знакомствам подруги. Трудоустройство состоялось по чужим документам, поскольку семья находилась в условиях острой материальной нужды, а длительные сроки оформления регистрации и получения временного убежища не давали возможности получить работу официально. Скопив немного денег, семья сняла квартиру вместе с другой подругой, выехавшей из Юго-Восточной Украины.

Помимо неформальных сетей, помощь беженцам оказывала местная администрация, Общественная палата, местное сообщество, которым удалось своевременно оказать материальную и медицинскую помощь, отправить детей беженцев в школы, предоставить временное проживание в санаториях, детских лагерях. Для оплаты проживания и питания в центрах временного размещения государство выплачивало 800 рублей в день на человека. Всего в стране действовали 576 центров, где располагалось около 30 тыс. чел. К концу 2016 г. перед закрытием поддержки по временному размещению украинских беженцев с января 2017 г., оставались 47 центров для 558 чел. (РИА Новости 2016). Закрытие центров происходило зачастую без заблаговременного информирования жильцов, большинство из которых были представителями уязвимых слоев населения - одинокие матери и многодетные семьи. Например, правозащитник из Калуги отмечает:

...поскольку федеральные субсидии закончились, регионалы быстренько всех беженцев попросили «на выход», и люди оказались перед стрессовой ситуацией, когда нужно было срочно искать где-то жилье, снимать его, арендовать, нужно было искать работу, и больше всех пострадали, конечно, матери-одиночки, воспитывающие трех детей, инвалиды, беременные.

В Калуге несколько человек с ограниченными возможностями были размещены в доме для престарелых и инвалидов. Что касается пожилых, многодетных семей и матерей-одиночек, то как в Калуге, так и в Казани, большинству приходилось решать вопросы поиска жилья в короткие сроки самостоятельно. Учитывая, что к 2017 г. внимание гражданского общества и благотворителей к беженцам снизилось, им было проблематично найти поддержку. Лишь отдельные беженцы были встречены радушно и получили временный приют от незнакомых людей. Как высказался один из респондентов, «что касается человеческого отношения, были просто потрясены глубиной доброты местного населения, казанцев» (мужчина, 48 лет). Другие, напротив, столкнулись с проблемами нежелания собственников сдавать квартиры вынужденным мигрантам с Донбасса:

Ой, нам очень тяжело снять квартиру, очень тяжело. Мы получается, приходим, я еще помню снимала одна, потому что муж постоянно работает, а я одна с ребенком, я везу ребенка на коляске, зима, на улице морозяка, февраль месяц, не тепло... с девочкой этой, риэлтером, мы подходим, они такие, вы что ... вы это .... Украины? Такие, фуу, еще с Донецка... хлоп дверью и такое было не раз. Вот 70 процентов квартир, 
которые мы смотрели, арендодатели ...фууу, с Украины, с Донецка, фууу... <..> Вообще, скотское какое-то отношение (женщина, 25 лет).

Объясняя подобные случаи, респонденты как правило, ссылались на то, что в понимании многих россиян украинские беженцы получают от государства больше, чем российские граждане, что вызывает «зависть» и «неприятие» в отношении «гостей».

Еще одной проблемой, с которой столкнулись беженцы стало трудоустройство. Стоит отметить, что среди лиц, получивших временное убежище, примерно поровну женщин и мужчин, около $70 \%$ - трудоспособного возраста, 23\% - дети до 15 лет (Госкомстат России 2018). Учитывая, что беженцы в большинстве своем расселялись не в пунктах временного проживания, а самостоятельно, и, соответственно, нуждались в средствах для аренды жилья, возможность заработка выступала ключевой проблемой. В этом отношении опрошенные выделяли несколько барьеров. Во-первых, нежелание работодателей брать на работу иностранцев. Связано это не с этнической дискриминацией, а с нежеланием работодателей взаимодействовать с отделом миграции, боязнью нарушить законодательство: «Не знаю, просто они усльишат слово "ФМС" и уже начинают чего-то бояться. Они даже толком не знают, чего, и все. Ну просто не хотят» (женщина среднего возраста). Во-вторых, стоимость патента, дающего разрешение на трудоустройство, превышает возможности ряда беженцев дополнительно оплачивать жилье и иметь средства на повседневные нужды:

На работу никуда ты ничего не попадешь - выживай как хочешь, нигде тебя не принимают, пока ты не сделаешь патент. Патент сделать - это $30000<\ldots>$. Ну, 24000 пусть его сделать и каждый месяц 4200 платить в течение года. Плюс квартира 18000 на всю семью. И где такие зарплаты? Таких денег не заработаешь нигде (мужчина, 37 лет).

Поэтому многие беженцы работают неформально. Среди опрошенных было немало тех, кто либо в настоящий момент, либо какое-то время назад имел опыт неформального трудоустройства. Беженцы, которые работали в России до начала конфликта, смогли трудоустроиться и остаться жить в стране. Так, мужчина, 40 лет, из Луганской области, отвечая на вопрос «Испытывали ли Вы сложности в трудоустройстве?», ответил: «Мне было не тяжело. Потому что на протяжении многих лет я выезжал в Россию. Работал здесь. И вот один человек с которым я очень давно работал, он меня сюда позвал».

Таким образом, можно увидеть, что беженцы из Украины используют тактики, которые, по словам де Серто, выступают способом согласования пространств, формирующихся власть имущими. По его теории, «применение стратегий позволяет создавать, упорядочивать и фиксировать пространства, в то время как тактики дают возможность лишь использовать, обходить или избегать эти пространства» (Certeau 1984: 30). В условиях вынужденного 
бегства и неопределенности среды, люди пытаются согласовать и привести в порядок «непонятное» и зачастую некомфортное пространство, созданное сложным сочетанием законодательных норм и практик официальных лиц и учреждений. Это происходит за счет неформальных социальных связей и отношений. Позиция властей по содействию беженцам создала условия для принятия этой категории мигрантов обществом, однако неопределенность правового статуса и барьеры на пути натурализации в России привели к тому, что потенциал формирования безопасных пространств жизнедеятельности беженцев имел множество ограничений.

\title{
«Пиши просто - частная поездка»: коллизии правого статуса и «полу-легальность»
}

Одновременно с попытками найти жилье и трудоустройство, беженцы решали вопросы правового статуса. Многие информанты обратили внимание на недостаток информации из официальных источников относительно того, каким образом оформить временное убежище, разрешение на временное проживание или гражданство. Надежда возлагалась на опыт и информацию других беженцев либо мигрантов из Украины:

\begin{abstract}
Отношение нормальное, но я вам хочу сказать, эти УФМС, что ни спросишь у них, ничего они не знают. Вот какой бы тебя вопрос не интересовал - не знают. Вот насчет переселения соотечественников, то есть, упрощенного получения гражданства - нет информации. <..> Мы узнаем только в интернете, а в интернете не вся правдивая информация бывает. <.. > Информацию узнаем друг через друга, где встретишь кого (женщина, 60 лет).
\end{abstract}

Нередки случаи, когда беженцев убеждали не указывать факта, что они приехали, спасаясь от конфликта, и таким образом не подавать на получение временного убежища. Впоследствии они испытали трудности получения разрешения на временное проживание:

Я попал, как раз, когда я сюда приезжал, мне сказали,-не пиши статус беженца, ничего, пиши просто - частная поездка. И теперь я заявление написал два года назад, чтоб мне дали квоту, на РВП дали, и прихожу к ним, спрашиваю,- Вам, говорят, звонили - нет. Идите, ждите звонка. $<$.. > Нигде никому никто не нужен. Все красиво в телевизоре, и в газетах, а в жизни - я лично сталкивался... Я уже здесь третий год. Я же говорю - всех отфутболивают (мужчина, 60 лет, Московская обл.)

Подобная ситуация «полу-легальности» статуса приводила к необходимости решать вопрос с регистрацией, получением РВП с помощью неформальных платежей, что предусматривало не только необходимость определенной денежной суммы, но и информации об алгоритме «успешных» действий, полученной от знакомых, которым можно доверять. Это наиболее остро сказывается на повседневности беженцев, обладающих 
наименьшими материальными ресурсами и испытывающих недостаток в поддерживающих сообществах.

В отдельных случаях беженцы сами предпочитали не регистрировать временное убежище, поскольку имели необходимость периодически возвращаться на Донбасс, а статус лишал их возможности регулярного выезда. Поездки, как правило, вызваны потребностью навестить престарелых родителей, проверить состояние жилища, оплатить коммунальные платежи, либо оформить документы. Необходимость постоянного продления документов также повлияла на нежелание оформлять документы на временное убежище. Многих беженцев, которые по тем или иным причинам не хотят возвращаться, пугает данная неопределенность. Они предпочитают не оформлять разрешение на работу, либо работать неформально, но оставаться в стране продолжительное время. Вместе с тем пожилые люди предпочитали оформлять временное убежище, поскольку трудоустроится официально с патентом им чрезвычайно сложно. Многие пожилые женщины и реже мужчины вынуждены выполнять функции семейной заботы - присматривать за внуками, готовить пищу, поскольку их дети работали сверхурочно или на нескольких работах.

По мнению опрошенных, программа по содействию добровольному переселению в Российскую Федерацию соотечественников - это очень проблематичный способ получения гражданства. Во-первых, существует проблема ограниченности выбора регионов для переселения. После вынужденной миграции, сопровождаемой тревогой, неуверенностью, весьма сложно снова решиться на переезд, сулящий неизвестность. Как отмечал де Серто (Ceteau 1984: 117): «пространство - это место, освоенное практикой», а люди, уверенные, что их тактики работают в определенном пространстве, скорее останутся на той территории, где они живут, несмотря на кажущуюся экономическую, а в нашем случае, и правовую рациональность переезда (Round 2005). Так, например, одна из респонденток живет с сестрой в регионе, который не входит в программу «Соотечественники». Она имеет регистрацию, работает, но не желает переехать в другой регион, поскольку считает, что не сможет в одиночку найти место регистрации для постоянного жительства, а также разорвать связь с сестрой, проживающей с ней. Во-вторых, существуют возрастные и профессиональные ограничения, которые накладывает программа - она исключает возможности людей предпенсионного или пенсионного возраста участвовать в ней. В-третьих, не учитывается факт переселения как вынужденного, со всем комплексом материальных, социальных и психологических проблем, с которыми столкнулись беженцы.

В интервью правозащитники отмечали, что беженцы из Украины редко обращались с жалобами дискриминации либо за решением правовых коллизий. Они предположили высокие «адаптивные» способности данной группы, некоторые даже высказали предположение об успешной 
«интеграции». Вместе с тем анализ интервью показал, что те из них, кто испытывает проблемы с правовым статусом, пытаются быть «невидимыми» и рассчитывают на собственные социальные сети и неформальные знания. Отсутствие проблемы проверки документов у украинских беженцев на улицах, с которыми сталкиваются, например, мигранты из Средней Азии (см.: Round, Kuznetsova 2018) и владение русским языком выступают поддерживающими факторами в данном контексте.

Противоречивость статуса беженцев с Донбасса, возможно, будет отчасти компенсирована при принятии законопроекта, который предусматривает амнистию для граждан Украины, получивших временное убежище, но просрочивших время своего пребывания в России (ТАCC 2018). В противном случае сложности поддержания необходимых тактик, позволяющих находиться в стране, и риски депортации приводят к неопределенному будущему.

\section{Заключение}

Исследование показало, что упрощенный режим получения российского гражданства и разрешения на временное проживание для выходцев из ЮгоВосточной Украины, признание документов, выданных гражданам Украины, проживающим на территориях отдельных районов Донецкой и Луганской областей не достаточны для решения жизненных потребностей беженцев. Бюрократия в миграционных службах, неясность и амбивалентность системы трудоустройства иностранных граждан, с которыми сталкиваются многие мигранты в России (см.: Malakhov, Simon 2018; Round, Kuznetsova 2016), затронули многих беженцев. Большую роль в повседневных тактиках, формирующих пространство беженцев, играют сети знакомств и неформальные знания. С точки зрения интерсекциональности, в наиболее сложной ситуации оказались люди предпенсионного и пенсионного возраста, которые не могут участвовать в Программе переселения соотечественников, не обладают ресурсами, необходимыми для неформальных тактик совладания с вынужденной миграцией и поиском правового статуса. Закрытие пунктов временного размещения в 2017 г. сказалось на судьбе многих представителей уязвимых групп населения - многодетных семей, одиноких родителей и инвалидов, которые не смогли обрести необходимый социальный и материальный капиталы для самостоятельного проживания в России.

Ситуация с вынужденной миграцией- продемонстрировала недостатки института социальной работы и прежде всего нехватку ресурсов для полноценного кейс-менеджмента. Безусловно, «административный ресурс» позволил разместить большое количество беженцев и оказать помощь в период пика конфликта, но отсутствие институтов, готовых планомерно отвечать на социальные потребности вынужденно перемещенных лиц, выступило одним из факторов их продолжительного нахождения в пространстве 
«полу-легальности». Можно предположить, что слаженная работа государственных и негосударственных институтов по преодолению проблем, вызванных вынужденной миграцией, и своевременное информирование о различных вариантах натурализации в России либо возвращения домой, могли бы содействовать формированию устойчивого и комфортного пространства повседневности беженцев.

\section{Выражение признательности}

Исследование проведено при поддержке British Academy. Автор также благодарит Центр превосходства Жана Монне в области европейских исследований VOICES +, финансируемого Программой Erasmus + Европейского Союза. В публикации отражено только мнение автора и Еврокомиссия не может нести ответственность за любое использование информации, содержащейся в ней. Автор выражает глубокую признательность респондентам, принявшим участие в исследовании, анонимным рецензентам и редакторам.

\section{Список источников}

Бойко И.А. (2015) Отношение молодежи Белгородской области к проблемам беженцев из Украины и Сирии. Научный альманах, 12-3 (14): 198-204.

Буртина Е. Ю., Коростелева Е. Ю., Симонов В.И. (2015) Россия как страна убежища. М.: Ваш Формат.

Волкова О.А., Оставная А.Н., Гребеникова Ю.А. (2016) Беженцы на территории Белгородской области: специфика адаптации и актуальные потребности. Социология и право, (3): 6-12.

ВЦИОМ (2014) Украинские бежениы в России. Доступно по ссылке: https://wciom. ru/index.php?id=236\&uid=757 (дата обращения: 12 мая 2017).

Голубь О.В., Безрукова А.Н. (2015) Особенности межэтнических отношений беженцев из Украины с жителями г. Волгограда и Волгоградской области. Вестник Волгоградского государственного университета. Серия 7: Философия. Социология и соииальные технологии, 4 (30): 89-94.

Гулина О.Р. (2016) Семантика миграционных терминов. Журнал исследований соииальной политики, 14 (3): 331-346.

Госкомстат России (2018) Численность вынужденных переселенщев, беженцев и лиц, получивших временное убежище. Доступно по ссылке: http://www.gks.ru/free_doc/ new_site/population/demo/tab-migr4.htm (дата обращения: 28 октября 2018).

Змеева О.В., Сулейманова О.А. (2015) «Север подставил плечо»: размещение и трудоустройство украинских «братьев» в Мурманской области. Труды Кольского научного центра РАН. Гуманитарные исследования, 1 (27): 7-29.

Константинов В.В., Мали Н.А. (2016) Особенности психологической адаптации младших школьников, вынужденно покинувших территорию Украины. Начальная школа, (2): 32-35. 
Мкртчян Н. (2002) Десятилетие вынужденной миграции в России. Демоскоn Weekly. 71-72. Доступно по ссылке: http://www.demoscope.ru/weekly/2002/071/tema01.php (дата обращения: 4 июня 2017).

Новости Интерфакс (2018) Ольга Кириллова: более 300 тылсяч украинщев получили гражданство РФ с 2014 года. Доступно по ссылке: https://www.interfax.ru/interview/628692 (дата обращения: 3 октября 2017).

ООН (2018) План гуманитарного реагирования. Январь-декабрь 2018. Доступно по ссылке: https://www.humanitarianresponse.info/sites/www.humanitarianresponse. info/files/documents/files/humanitarian_response_plan_2018_ru.pdf (дата обращения: 15 мая 2018).

Панич О.Е., Агапова Э.Э. (2015) Психологические проявления адаптации вынужденных мигрантов из Украины. APRIORI. Серия: Гуманитарные науки, (3): 47-47.

Петров И. (2016) В МВД рассказали, сколько украинцев стали россиянами. Российская газета. Доступно по ссылке: https://rg.ru/2016/10/27/v-mvd-rasskazali-skolkoukraincev-stali-rossiianami.html (дата обращения: 3 января 2017).

Президент России (2017) Указ о признании документов, выданных гражданам Украины и лицам без гражданства, проживающим на территориях отдельных районов Донеикой и Луганской областей Украины. Доступно по ссылке: http:// kremlin.ru/events/president/news/53895 (дата обращения: 4 марта 2017).

Раунд Д., Уильямс К., Роджерс П. (2010) Повседневные тактики и пространства власти в повседневной жизни: роль неформальных экономик в постсоветской Украине и аспекты социальной политики. Журнал исследований социальной политики, 8 (3): 405-424.

РИА Новости (2016) В России продолжают действовать 47 ПВР для беженцев с Украины. Доступно по ссылке: https://ria.ru/society/20161027/1480119047.html (дата обращения: 28 мая 2018).

Рязанцев С., Скоробогатова В. (2016) Украинская миграция в приоритетах развития России. Международные процессы, 14 (1):38-51.

ТАСС (2017) Миграционное управление МВД продолжит выполнять возложенные на ФМС задачи. Доступно по ссылке: http://tass.ru/obschestvo/3922240 (дата обращения: 28 февраля 2017).

ТАСС (2018) В Госдуму внесли проект о миграционной амнистии для беженцев с Украины. Доступно по ссылке: http://tass.ru/politika/5321852 (дата обращения: 26 июня 2018).

Федеральный закон (2016) О внесении изменений в статью 8 Федерального закона «О правовом положении иностранных граждан в Российской Федераџии» № 129-ФЗ от 01.05.2016 г.

Atkinson R., Flint J. (2001) Accessing Hidden and Hard-to-reach Populations: Snowball Research Strategies. Social Research Update, Issue 33, Department of Sociology, University of Surrey.

Anthias F. (2012) Transnational Motilities, Migration Research and Intersectionality. Towards a Translocational Frame. Nordic Journal of Migration Research, 2 (2): 102-110.

Bürkner H. J. (2012) Intersectionality: How Gender Studies Might Inspire the Analysis of Social Inequality among Migrants. Population, Space and Place, 18 (2): 181-195. 
Certeau M. de (1984) The Practice of Everyday Life. Berkeley: University of California Press.

Denisova A. (2018) A Case Study of the UK and Russia's Approaches to Syrian Refugees. The International Journal of Human Rights, 22 (3):370-392.

IOM (2018) IOM Ukraine Crisis Response Plan (2018). Available at: http://www.iom.org. ua/sites/default/files/crisis_response_plan_2018-final.pdf (accessed 3 October 2018).

Kubal A. (2013) Conceptualizing Semi-legality in Migration Research. Law \& Society Review, 47 (3): 555-587.

Kubal A. (2016) Refugees or Migrant Workers? A Case Study of Undocumented Syrians in Russia - LM and Others v Russia (ECHR 14 March 2016). Journal of Immigration, Asylum and Nationality Law, (30): 1-26.

Malakhov V.S., Simon M.E. (2018) Labour Migration Policy in Russia: Considerations on Governmentality. International Migration, 56 (3): 61-72.

Mukomel V. (2017) Migration of Ukrainians to Russia in 2014-2015. Discourses and Perceptions of the Local Population. A. Pikulicka-Wilczewska, G. Uehling (eds.) Migration and the Ukraine Crisis. A Two-Country Perspective. Bristol: E-International relations publishing: 105-115.

Pilkington H., Flynn M. (1999) From 'Refugee' to 'Repatriate': Russian Repatriation Discourse in the Making. R. Black, K. Koser (eds.) The end of the Refugee Cycle. New York: Berghahn Books: 171-197.

Round J. (2005) Rescaling Russia's Geography: the Challenges of Depopulating the Northern Periphery. Europe-Asia Studies, (57): 705-727.

Round J., Kuznetsova I. (2016) Necropolitics and the Migrant as a Political Subject of Disgust: The Precarious Everyday of Russia's Labour Migrants. Critical Sociology, 42 (7-8): 1017-1034.

Round J., Kuznetsova I. (2018) States of Exception in a Super-Diverse City: the Compromised Mobility of Moscow's Labor Migrants. M. Laurelle, C. Schenk (eds.) Eurasia on the Move Interdisciplinary Approaches to a Dynamic Migration Region. Washington: The George Washington University: 107-118.

Stegniy V.N., Antipyev K.A., Litvinova, S.V. (2016) Refugees from South-Eastern Ukraine in Russia: Sociological Analysis. Indian Journal of Science and Technology, 9 (39): 103-108.

UNHCR (2016) Ukraine UNHCR operational update 14 May - 10 June 2016. Доступно по ссылке: https://reliefweb.int/sites/reliefweb.int/files/resources/UNHCR\%20Operational\%20Update\%20on\%20the\%20Ukraine\%20Situation\%20-\%2014MAY-10JUN16. pdf (дата обращения: 11 января 2017).

Williams C. C., Round J., Rodgers P. (2014) The Role of Informal Economies in the PostSoviet World: The end of transition? New York: Routledge.

Yuval-Davis N. (2011) The Politics of Belonging: Intersectional Contestations. Sage: London. 


\title{
REFUGEES FROM UKRAINE IN RUSSIA: MIGRATION POLICY AND EVERYDAY LIFE
}

\begin{abstract}
Since the onset of conflict in 2014, more than one million people have fled from south-east Ukraine to Russia. These displaced people fall into numerous categories in Russia and use a variety of formal and informal practices 'to cope' and find employment. This article does use not a formal definition of 'refugee', but instead relies on the self-identification of people as refugee, on the basis of interviews with displaced people and with NGOs, diaspora leaders and migration experts. The paper's theoretical framework is based on de Certeau's concept of tactics and coping, intersectionality and the concept of 'semi-legality'. Firstly, it examines how the simplified route of applying for Russian citizenship/residence permits do not resolve refugees' issues. For example, The Compatriot Resettlement Program does not reflect the specific needs of forced displaced people, has a limited choice of regions where people can settle and has age limitations. It then explores how the issues surrounding the legal status of this group has made the process of forming safe spaces for displaced people very problematic. With a lack of institutional support available to respond to social needs, and issues around their legal status, informal networks became crucial for the sharing of knowledge and support for all aspects of refugees' lives. The paper then details how the situation of semi-legality is especially challenging for the elderly as well as the displaced with few material resources, who lack strong support networks. The paper concludes by arguing that there is a need for a coordinated approach to resolving the social and legal problems refugees face, which were also gender and age sensitive. The nature of this space would also depend on the attitudes of the host society towards 'others' as played out in daily interactions, institutional practices and the implementation of migrant rights.
\end{abstract}

Keywords: refugees, Ukraine, everyday life, migration policy in Russia, asylum

DOI: $10.17323 / 727-0634-2018-16-4-577-594$

\section{References}

Atkinson R., Flint J. (2001) Accessing Hidden and Hard-to-reach Populations: Snowball Research Strategies. Social Research Update, Issue 33, Department of Sociology, University of Surrey.

Irina B. Kuznetsova - PhD, Birmingham Fellow, School of Geography, Earth and Environmental Sciences, University of Birmingham, United Kingdom. Email: i.kuznetsova@bham.ac.uk 
Anthias F. (2012) Transnational Motilities, Migration Research and Intersectionality. Towards a Translocational Frame. Nordic Journal of Migration Research, 2 (2): 102-110.

Boyko I. A. (2015) Otnosheniye molodezhi Belgorodskoy oblasti k problemam bezhentsev iz Ukrainy i Sirii [Belgorod Youth's Attitudes to the Issues of Refugees from Ukraine and Syria]. Nauchnyy al'manakh [Academic Review], 12-3 (14): 198-204.

Burtina, E.J., Korosteleva, E.J., Simonov, V.I. (2015) Rossija kak strana ubezhishha [Russia as a Country of Asylum]. Moscow: Vash Format.

Bürkner H. J. (2012) Intersectionality: How Gender Studies Might Inspire the Analysis of Social Inequality among Migrants. Population, Space and Place, 18 (2): 181-195.

Certeau M. de (1984) The Practice of Everyday Life. Berkeley: University of California Press.

Denisova A. (2018) A Case Study of the UK and Russia's Approaches to Syrian Refugees. The International Journal of Human Rights, 22 (3): 370-392.

Golub' O.V., Bezrukova A.N. (2015) Osobennosti mezh·etnicheskikh otnosheniy bezhentsev iz Ukrainy s zhitelyami g. Volgograda i Volgogradskoy oblasti [Special Features of Inter-ethnic Relations of Refugees from Ukraine with Residents of Volgograd and Volgograd Oblast]. Vestnik Volgogradskogo gosudarstvennogo universiteta. Seriya 7: Filosofiya. Sotsiologiya i sotsial'nyye tekhnologii [Science Journal of Volgograd State University. Philosophy. Sociology and social technologies], 4 (30): 89-94.

Gulina O.R. (2016) Exploring the Semantics of Migration Terminology. The Journal of Social Policy Studies, 14 (3): 331-346.

Interfax (2018) Ol'ga Kirillova: boleye 300 tysyach ukraintsev poluchili grazhdanstvo RF s 2014 goda [Olga Kirillova: More than 300 Thousand Ukrainians Received Russian Citizenship from 2014]. Available at: https://www.interfax.ru/interview/628692 (accessed 03 October 2018).

IOM (2018) IOM Ukraine Crisis Response Plan (2018). Available at: http://www.iom.org. ua/sites/default/files/crisis_response_plan_2018-final.pdf (accessed: 03 October 2018)

Konstantinov V.V., Mali N. A. (2016) Osobennosti psikhologicheskoy adaptatsii mladshikh shkol'nikov, vynuzhdenno pokinuvshikh territoriyu Ukrainy [Special Features of Psychological Adaptation of Primary School Children, Forcibly Displaced from Ukraine]. Nachal'naya shkola [Primary School], (2):32-35.

Kubal A. (2013) Conceptualizing Semi-legality in Migration Research. Law \& Society Review, 47 (3): 555-587.

Kubal A. (2016) Refugees or Migrant Workers? A Case Study of Undocumented Syrians in Russia - LM and Others v Russia (ECHR 14 March 2016). Journal of Immigration, Asylum and Nationality Law, (30): 1-26.

Malakhov V.S., Simon M.E. (2018) Labour Migration Policy in Russia: Considerations on Governmentality. International Migration, 56 (3): 61-72.

Mkrtchyan N. (2002) Desjatiletie vynuzhdennoj migracii v Rossii [A Decade of Forced Migration in Russia]. Demoscope Weekly. 71-72. Available at: http://www.demoscope.ru/ weekly/2002/071/tema01.php (accessed 04 June 2017). 
Mukomel V. (2017) Migration of Ukrainians to Russia in 2014-2015. Discourses and Perceptions of the Local Population. A. Pikulicka-Wilczewska, G. Uehling (eds.) Migration and the Ukraine Crisis. A Two-Country Perspective. Bristol: E-International relations publishing: 105-115.

Panich O.E., Agapova E.E. (2015) Psikhologicheskiye proyavleniya adaptatsii vynuzhdennykh migrantov iz Ukrainy [Psychological Manifestations of Adaptation of Forced Migrants from Ukraine]. APRIORI. Ceriya: Gumanitarnyye nauki [APRIORY. Humanities], (3): 47-47.

Petrov I. (2016) V MVD rasskazali, skol'ko ukraincev stali rossijanami [MIA Told How Many Ukrainians Became Russian Citizens]. Rossijskaja gazeta [Russian Newspaper] Available at: https://rg.ru/2016/10/27/v-mvd-rasskazali-skolko-ukraincev-stali-rossiianami.html (accessed 3 January 2017).

Pilkington H., Flynn M. (1999) From 'Refugee' to 'Repatriate': Russian Repatriation Discourse in the Making. R. Black, K. Koser (eds.) The End of the Refugee Cycle. New York: Berghahn Books: 171-197.

President of Russia (2017) Ukaz o priznanii dokumentov, vydannyh grazhdanam Ukrainy i licam bez grazhdanstva, prozhivajushim na territorijah otdel'nyh rajonov Doneckoj i Luganskoj oblastej Ukrainy [Decree on the Recognition of Documents Issued to Citizens of Ukraine and Stateless Persons Residing in the Territories of Certain Districts of Donetsk and Lugansk Regions of Ukraine]. Available at: http://kremlin.ru/events/president/news/53895 (accessed 4 March 2017).

RIA Novosti (2016) V Rossii prodolzhajut dejstvovat' 47 PVR dlja bezhencev s Ukrainy [Tin Russia, 47 Centers for Temporal Accommodation Continue Work for Refugees from Ukraine]. Availabe at: https://ria.ru/society/20161027/1480119047.html (accessed 28 May 2018).

Round J. (2005) Rescaling Russia's Geography: The Challenges of Depopulating the Northern Periphery. Europe-Asia Studies, (57): 705-727.

Round J., Kuznetsova I. (2016) Necropolitics and the Migrant as a Political Subject of Disgust: The Precarious Everyday of Russia's Labour Migrants. Critical Sociology, 42 (7-8): 1017-1034.

Round J., Kuznetsova I. (2018) States of Exception in a Super-Diverse City: the Compromised Mobility of Moscow's Labour Migrants. M. Laurelle, C. Schenk (eds.) Eurasia on the Move: Interdisciplinary Approaches to a Dynamic Migration Region. Washington: The George Washington University: 107-118.

Ryazantsev S., Skorobogatova V. (2016) Ukrainskaya migratsiya v prioritetakh razvitiya Rossii [Ukrainain Migration among the Priorities of Russian Development]. Mezhdunarodnyye protsessy [International Processes], 14 (1):38-51.

Stegniy V.N., Antipyev K.A., Litvinova, S.V. (2016) Refugees from South-Eastern Ukraine in Russia: Sociological Analysis. Indian Journal of Science and Technology, 9 (39): 103-108.

TASS (2018) V Gosdumu vnesli proyekt o migratsionnoy amnistii dlya bezhentsev s Ukrainy [A Draft Law has been Submitted to State Duma Regarding Migration Amnesty for Refugees from Ukraine]. Available at: http://tass.ru/politika/5321852 (accessed 26 June 2018).

TASS (2017) Migratsionnoye upravleniye MVD prodolzhit vypolnyat' vozlozhennyye na FMS zadachi [Migration Department of MIA will Continue Fulfil Federal Migration Service Tasks]. Available at: http://tass.ru/obschestvo/3922240 (accessed 28 February 2017). 
UNHCR (2016) Ukraine UNHCR operational update 14 May - 10 June 2016. Available at: https://reliefweb.int/sites/reliefweb.int/files/resources/UNHCR\%20Operational\%20Update $\% 20$ on\%20the \%20Ukraine\%20Situation\%20-\%2014MAY-10JUN16.pdf (accessed 11 January 2017).

Volkova O.A., Ostavnaya A.N., Grebenikova Yu.A. (2016) Bezhentsy na territorii Belgorodskoy oblasti: spetsifika adaptatsii i aktual'nyye potrebnosti [Refugees in a Territory of Belgorod Oblast: Aspects of Adaptation and Topical Needs]. Sotsiologiya i pravo [Sociology and Law], (3): 6-12.

VTSIOM (2014) Ukrainskiye bezhentsy v Rossii [Ukrainian Refugees in Russia]. Available at: https://wciom.ru/index.php?id=236 (accessed 12 May 2017).

Williams C. C., Round J., Rodgers P. (2014) The Role of Informal Economies in the PostSoviet World: The End of Transition? New York: Routledge.

Yuval-Davis N. (2011) The Politics of Belonging: Intersectional Contestations. Sage: London.

Zmeyeva O.V., Suleymanova O.A. (2015) 'Sever podstavil plecho': razmeshcheniye i trudoustroystvo ukrainskikh 'brat'yev' v Murmanskoy oblasti ['The North Gave a Helping Hand': Housing and Employment of Ukrainian 'Brothers' in Murmansk Oblast]. Trudy Kol'skogo nauchnogo tsentra RAN. Gumanitarnyye issledovaniya [Bulletin of Kola's Academic Center of RAS], 1 (27): 7-29. 